Article

\title{
Inundation Exposure Assessment for Majuro Atoll, Republic of the Marshall Islands Using A High-Accuracy Digital Elevation Model
}

\author{
Dean Gesch ${ }^{1, *(\mathbb{D}, \text { Monica Palaseanu-Lovejoy }}{ }^{2}$, Jeffrey Danielson ${ }^{1}{ }^{1}$, Charles Fletcher $^{3}$, \\ Maria Kottermair ${ }^{4}\left(\mathbb{D}\right.$, Matthew Barbee ${ }^{3}$ and Andrea Jalandoni ${ }^{5}$ \\ 1 U.S. Geological Survey, Earth Resources Observation and Science Center, Sioux Falls, SD 57198, USA; \\ daniels@usgs.gov \\ 2 U.S. Geological Survey, Geology, Minerals, Energy, \& Geophysics Science Center, Reston, VA 20192, USA; \\ mpal@usgs.gov \\ 3 Coastal Geology Group, Department of Geology and Geophysics, School of Ocean and Earth Science and \\ Technology, University of Hawaii, Honolulu, HI 96822, USA; fletcher@soest.hawaii.edu (C.F.); \\ mbarbee@hawaii.edu (M.B.) \\ 4 Pacific Islands Climate Adaptation Science Center, University of Guam, Mangilao 96923, Guam; \\ mariakottermair@triton.uog.edu \\ 5 Griffith Centre for Social and Cultural Research, Griffith University, Queensland, QLD 4122, Australia; \\ a.jalandoni@griffith.edu.au \\ * Correspondence: gesch@usgs.gov; Tel.: +1-605-594-6055
}

Received: 8 November 2019; Accepted: 27 December 2019; Published: 2 January 2020

\begin{abstract}
Majuro Atoll in the central Pacific has high coastal vulnerability due to low-lying islands, rising sea level, high wave events, eroding shorelines, a dense population center, and limited freshwater resources. Land elevation is the primary geophysical variable that determines exposure to inundation in coastal settings. Accordingly, coastal elevation data (with accuracy information) are critical for assessments of inundation exposure. Previous research has demonstrated the importance of using high-accuracy elevation data and rigorously accounting for uncertainty in inundation assessments. A quantitative analysis of inundation exposure was conducted for Majuro Atoll, including accounting for the cumulative vertical uncertainty from the input digital elevation model (DEM) and datum transformation. The project employed a recently produced and validated DEM derived from structure-from-motion processing of very-high-resolution aerial imagery. Areas subject to marine inundation (direct hydrologic connection to the ocean) and low-lying lands (disconnected hydrologically from the ocean) were mapped and characterized for three inundation levels using deterministic and probabilistic methods. At the highest water level modeled $(3.75 \mathrm{ft}$, or $1.143 \mathrm{~m})$, more than $34 \%$ of the atoll study area is likely to be exposed to inundation ( $68 \%$ chance or greater), while more than $20 \%$ of the atoll is extremely likely to be exposed ( $95 \%$ chance or greater). The study demonstrates the substantial value of a high-accuracy DEM for assessing inundation exposure of low-relief islands and the enhanced information from accounting for vertical uncertainty.
\end{abstract}

Keywords: inundation; flooding; sea-level rise; digital elevation model; vertical accuracy; uncertainty; confidence level; error propagation; coastal vulnerability

\section{Introduction}

Low-lying islands are vulnerable to inundation (coastal flooding), whether the increased water levels are from episodic events (storm surge, wave run-up, king tides) or from chronic conditions (long-term sea-level rise). Atolls are particularly vulnerable to the effects of sea-level rise in the form of 
shoreline erosion, inundation, and saltwater intrusion into fresh groundwater [1]. Numerous studies have assessed climate change-driven impacts and other environmental factors on the resilience of low-lying islands, including biophysical changes [2-8] and biodiversity consequences [9,10].

Coastal vulnerability is inherently spatial, and this geographic dependence requires that risk assessments of places, people, and assets be location specific [11]. For such assessments, mapping and characterization of physical hazards are critical, and the need is great for detailed, localized analyses rather than more general coarse-scale assessments [6]. In particular, detailed knowledge of the topography is essential for assessing coastal inundation exposure, especially on low-lying lands, and the lack of suitable elevation data has been noted [1,12-14].

Majuro Atoll, Republic of the Marshall Islands, in the central Pacific bears all the marks of high coastal vulnerability, including low-lying islands [13], rising sea level (far greater than the global average) [15,16], high wave events [17,18], eroding shorelines [3], a dense population center in an expanding urban area [3], and limited freshwater resources [19]. Existing general assessments [2,9,10] lack the spatially explicit detail that is needed for informing local adaptation planning, in part due to the coarse nature of the topographic information used. New remote sensing-derived high-resolution, high-accuracy elevation data for Majuro Atoll, including comprehensive uncertainty information [13], represent a valuable resource for coastal hazard assessment. Previous research has demonstrated the importance of using high-accuracy elevation data and rigorously accounting for uncertainty in coastal flooding assessments [20-26]. The focus of this paper is a quantitative inundation exposure assessment complete with best practices for considering vertical uncertainty, that demonstrates the advantages of using a remote sensing-derived high-resolution, high-accuracy elevation model to produce spatially explicit hazard information. The results are a first for Majuro Atoll and are useful for climate change adaptation planning and mitigation.

\section{Materials and Methods}

\subsection{Study Area}

Majuro Atoll (Figure 1), located in the central Pacific Ocean approximately $3800 \mathrm{~km}$ southwest of Hawaii, is a roughly oval-shaped string of over 60 low-relief islands that encircle a lagoon of about $300 \mathrm{~km}^{2}$. It is in the Ratak (eastern) Chain of the Marshall Islands and is centered at $7^{\circ} 07^{\prime} \mathrm{N}$ latitude and $171^{\circ} 12^{\prime} \mathrm{E}$ longitude. Majuro, the capital city of the Republic of the Marshall Islands (RMI), is located at the eastern end of the atoll. The total land area of the atoll is about $10 \mathrm{~km}^{2}$. The portion of the atoll used in this study is the entire connected southern half that runs from Laura in the west to Rita in the northeast-a length of about $48 \mathrm{~km}$.

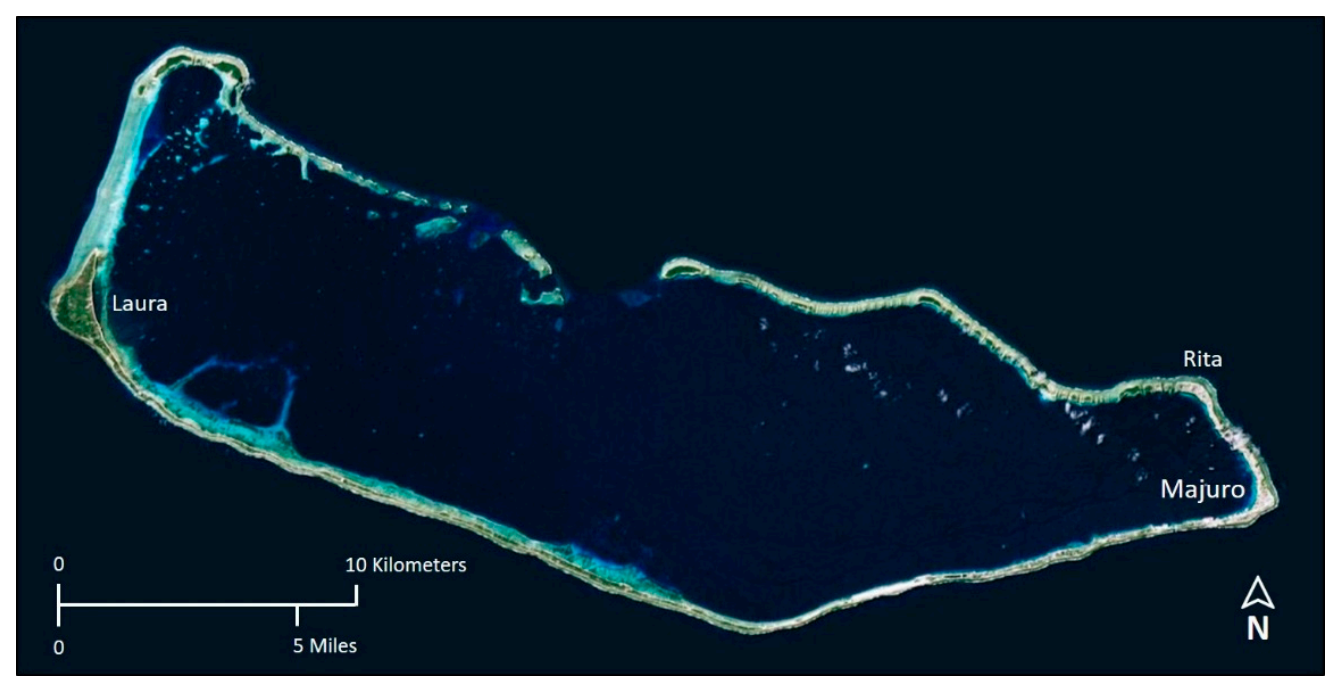

Figure 1. Majuro Atoll, Republic of the Marshall Islands. 


\subsection{Digital Elevation Models}

The high-resolution, high-accuracy digital elevation model (DEM) used in this assessment is derived from unmanned aircraft system (UAS) imagery processed with structure-from-motion (SfM) techniques [13]. The 1-m spatial resolution DEM represents bare ground conditions, as vegetation and buildings have been removed (seawalls and other shoreline protection structures were not removed). The dense three-dimensional (3D) point cloud was automatically classified in Agisoft PhotoScan into two classes, ground points (bare earth) and unclassified (vegetation, buildings, water, and noise) points. This classification was further manually and iteratively refined to derive a bare-earth DEM. Each iteration consisted in manually comparing the previous bare-earth DEM with the 3D red, green, blue (RGB) colored point cloud and area SfM orthomosaic to identify and fix points misclassified by the automatic classifier.

Numerous global or near-global DEMs are available and they have been used extensively for sea-level rise and coastal flooding assessments [25]. These DEMs have been assessed for Majuro Atoll to help demonstrate the advantages of the high-accuracy elevation data for inundation modeling. The following DEMs, summarized in Table 1, are included: Shuttle Radar Topography Mission (SRTM) [27], ASTER Global Digital Elevation Model (GDEM) [28], ALOS World 3D (AW3D30) [29], and TerraSAR-X add-on for Digital Elevation Measurement (TanDEM-X) [30]. In addition to these freely available global DEMs, a commercial DEM product derived from WorldView high-resolution satellite stereo-optical imagery, the DigitalGlobe Advanced Elevation Series (DG-AES) [31], was also included in the analysis.

Table 1. Digital elevation models available for Majuro Atoll.

\begin{tabular}{ccc}
\hline DEM & Grid Spacing & Accuracy Specification (RMSE $^{\mathbf{1}}$ in $\mathbf{~ m}$ ) \\
\hline UAS-SfM $^{2}$ & $1 \mathrm{~m}$ & 0.30 \\
SRTM $^{3}$ & 1 -arc-s $(30 \mathrm{~m})$ & 9.73 \\
ASTER GDEM $^{4}$ & 1 -arc-s $(30 \mathrm{~m})$ & 10.20 \\
AW3D30 $^{5}$ & 1 -arc-s $(30 \mathrm{~m})$ & 5.0 \\
TanDEM-X $^{6}$ & 0.4 -arc-s $(12 \mathrm{~m})$ & 6.08 \\
DG-AES $^{7}$ & $2 \mathrm{~m}$ & 2.43 \\
\hline
\end{tabular}

${ }^{1}$ RMSE: root mean square error. ${ }^{2}$ UAS-SfM: Unmanned aircraft system-Structure-from-motion. ${ }^{3}$ SRTM: Shuttle Radar Topography Mission. ${ }^{4}$ ASTER GDEM: ASTER Global Digital Elevation Model. ${ }^{5}$ AW3D30: ALOS World 3D. ${ }^{6}$ TanDEM-X: TerraSAR-X add-on for Digital Elevation Measurement. ${ }^{7}$ DG-AES: DigitalGlobe-Advanced Elevation Series.

\section{Accuracy Assessment}

To characterize vertical uncertainty, the absolute vertical accuracy of each of the DEMs was measured by comparison with a very large set of independent reference points. The nearly 69,000 high-accuracy geodetic control points from a Global Navigation Satellite System (GNSS) real-time kinematic (RTK) survey have a vertical root mean square error (RMSE) of $0.03 \mathrm{~m}$ [13], and so they are an excellent reference dataset with which to validate the DEMs. To gather the required error statistics that describe vertical accuracy, the independent reference points are compared to the DEMs at each point location. In each case, the DEM elevation is extracted via bilinear interpolation at the exact point location and the difference in reference elevation and DEM elevation is recorded, with the difference representing the vertical error. The differencing operation is done by subtracting the reference point elevation from the DEM elevation. In this way, the difference statistics from the full set of points are easy to interpret; that is, a positive mean error indicates that on average the DEM is too high (the DEM has a positive bias). Conversely, a negative mean error indicates that on average the DEM is too low (it has a negative bias).

Before comparing the DEM and the reference data, both datasets must be in the same vertical reference frame, so that the difference statistics do not contain any artificial biases. The DEMs and reference point data include a mix of different vertical reference systems: SRTM, ASTER GDEM, and AW3D30 are referenced to the Earth Gravitational Model 1996 (EGM96) geoid; TanDEM-X is referenced 
to the World Geodetic System 1984 (WGS84)-G1150 ellipsoid; and the UAS-SfM DEM and check points are referenced to the International Terrestrial Reference Frame 2008 (ITRF2008) ellipsoid. The check points and each DEM were brought into the same vertical reference frame with a standard procedure employed in DEM assessments [32].

\subsection{Tidal Datums}

The high-resolution, high-accuracy UAS-SfM DEM was originally produced in ellipsoid referenced vertical coordinates (due to the geodetic control point information acquired via GNSS survey that was used to georeference the UAS imagery), but was transformed to orthometric (mean sea level referenced) elevations with a local geoid model developed from leveled benchmarks located throughout the atoll [13]. Long-term water level data were processed to derive tidal datums so that inundation modeling could be done in a sea-level reference frame. Hourly water level data from the Majuro tide gauge (located on the lagoon shoreline at the east end of the atoll) for the period May 1993 through July 2017 were downloaded from the Pacific Sea Level and Geodetic Monitoring Project (Australian Bureau of Meteorology) [33], which includes 12 gauges in the Pacific that are part of the Permanent Service for Mean Sea Level (PSMSL) network [34]. The hourly data were processed to derive the vertical offsets from local mean sea level (LMSL) for mean lower low water (MLLW) and mean higher high water (MHHW). Based on the processed tide gauge record, MLLW is $0.616 \mathrm{~m}$ below LMSL and MHHW is $0.645 \mathrm{~m}$ above LMSL, resulting in a mean tidal range of $1.261 \mathrm{~m}$.

\subsection{Inundation Assessment Parameters}

When conducting an inundation exposure assessment, a critical parameter is the increment of water level increase that is modeled. Previous research has established that the chosen water level increment must be supported by the inherent accuracy of the underlying elevation data [23-25,35]. In other words, relative to the DEM uncertainty (vertical error), the increment must not be so small that it is "within the noise"; thus, a highly accurate DEM is required to model fine increments of water level increase with high confidence results. Using published methods [25], the minimum allowable increments of increased water level at specific confidence levels were calculated for the UAS-SfM DEM based on its measured vertical accuracy. Modeling inundation using a DEM is essentially an elevation contouring operation wherein the "contour" is delineated at the elevation of the increased water level. Consequently, the use of contour accuracy standards is an effective way to determine the increment of water level increase (or the contour interval) at a specified statistical confidence level given the vertical accuracy of the DEM [25].

\subsection{Inundation Mapping}

The selected water levels were mapped with three approaches, including one that does not consider vertical uncertainty (elevation model error) and two others that account for vertical uncertainty in different ways. The inundation model is a simple hydrostatic [36] model (still water or flat water, so no effect of waves), which is often referred to as a bathtub model. Bathtub inundation has also been called single-value surface [35], equilibrium [37], planar [38], and static inundation [39]. In this study, inundation from a direct surface hydrologic connection to the ocean [40] is marine inundation, and the low elevations below the specified water level that are disconnected hydrologically from the ocean are designated as low-lying areas. In some cases, these areas have been referred to as areas with "groundwater inundation" [41,42], although the inundation may be due to not only raised groundwater levels but also king tides, run-up of high waves, runoff from precipitation, or some combination of these factors. The importance of mapping these low-lying areas has been recognized in numerous studies $[8,22,43-49]$. 


\subsubsection{Deterministic}

The simplest, and most often employed, method of mapping projected inundation onto the land surface raises the water level on a coastal DEM by delineating all areas that fall below a specified elevation (at the height of the raised water level). This approach is called deterministic as the location and extent of the projected inundated area are determined simply by where the specified elevation of the raised water level falls on the land [25]. Exposure assessments that use the deterministic mapping approach have no indication of the quality of the mapping, nor is there any statement of confidence level of the results. The primary limitation of deterministic mapping is that the implications of vertical uncertainty (elevation error) are unrepresented and cannot be factored into the use of the assessment results. The user of such an assessment is provided with no information about the quality of the results. For this study, deterministic mapping is included to help demonstrate its limitations and the increased information in inundation exposure mapping methods that consider the inherent vertical uncertainty present in all elevation-based assessments.

\subsubsection{Modified Deterministic}

An alternative, and improved, approach to simple deterministic mapping considers vertical uncertainty by applying a global error metric associated with the DEM, such as the widely used RMSE, or a related measure like "linear error at 95\% confidence" (LE95) [50]. The modified deterministic approach [25] equally applies the full global error everywhere, thereby assuming that all areas are subject to the full range of vertical error and the results reflect a range incorporating the minimum and maximum extremes of error. The full vertical error is subtracted from and added to the elevation of the raised water level, and then those two elevations are used to delineate the minimum and maximum projected inundation zones. Each delineation is still a deterministic mapping approach, thus the name, modified deterministic. This modified approach has the advantage over the simple deterministic approach because it accounts for vertical uncertainty by bounding the projected area and assigning a confidence label based on the portion of the full error probability distribution represented by the error metric (for instance $68 \%$ confidence for RMSE or $95 \%$ confidence in the case of LE95). For assessments conducted with the modified deterministic method, the confidence level indicates how confident a user can be that the true extent of the projected inundation zone is contained within the stated range (between the minimum and maximum areas).

\subsubsection{Probabilistic}

The third approach to inundation mapping includes the most complete treatment of vertical uncertainty. The probabilistic method [25] produces results that indicate the likelihood, or probability, of any location falling above or below a specified elevation (the height of the raised water level in an inundation exposure assessment). In implementing the method, the elevation error is modeled and then that error is propagated spatially through Monte Carlo simulation [51] using maps of the spatial distribution of probable errors. Random error fields that match the error distribution of the DEM (as derived from a vertical accuracy assessment) are generated and applied spatially. To account for spatial autocorrelation in the errors [52], spatial filtering using a low pass, or smoothing, filter is performed before the error model is applied to the DEM in each realization [52-54]. For this study, the Monte Carlo simulation included 750 realizations of probable cumulative vertical error to build the spatial map of inundation probability at the given water level scenarios. Note that the inundation probability in this case only considers elevation uncertainty and water level recurrence (or return interval) is not included. For this study, three discrete water levels were modeled (see Section 3.1), although the probability of future water levels has been incorporated into some previous inundation assessments [21].

There is a rich heritage of treating elevation error probabilistically [52,55-57], and the method has been successfully applied and its advantages demonstrated in numerous recent sea-level rise and 
inundation assessment studies [21,46,49,53,58-62]. For users of an assessment conducted with the probabilistic method, the stated probability indicates the likelihood, or chance, that the mapped area will be impacted at the specified increased water level, for example a $68 \%$ chance (or at least 68 times out of 100) that the area will be inundated.

\section{Results}

\subsection{Cumulative Vertical Uncertainty and Corresponding Minimum Inundation Levels}

The primary source of vertical uncertainty in an inundation exposure assessment is the DEM error. For this reason, using a high-accuracy DEM is desirable and allows fine increments of water level increases to be modeled, which is especially important for low-relief environments. Figure 2 shows the elevation error statistics for the UAS-SfM DEM of Majuro Atoll as determined in the absolute vertical accuracy assessment using the reference GNSS survey points. For purposes of inundation modeling, there is an additional source of vertical accuracy that should also be considered. As previously stated, the UAS-SfM DEM's native vertical coordinates are ellipsoid referenced. However, it is important to include local water level information when mapping projected inundation [63] by delineating impact areas above the high tide line as areas below this line are already subject to periodic inundation from the normal action of tides. To do such delineation, the DEM must first be transformed to orthometric elevations from its native ellipsoid referenced elevations. The required transformation is done by applying the local geoid; however, the geoid model also has vertical uncertainty that must be considered. The vertical uncertainty of the local geoid model is estimated at $0.061 \mathrm{~m}$ (one sigma error) [64], which is the standard deviation of the differences between the predicted point values and the actual point values derived from cross validation of the results of empirical Bayesian kriging used to generate the geoid surface [13]. The geoid error of $0.061 \mathrm{~m}$ is combined with the DEM error of $0.179 \mathrm{~m}$ (RMSE) via a root sum of squares (or summing in quadrature) resulting in a cumulative vertical uncertainty of $0.189 \mathrm{~m}$ (7.44 inches [in.]) RMSE. When accounting for vertical uncertainty in inundation assessments, combining DEM error and datum transformation error into cumulative vertical uncertainty is a recognized best practice that has been successfully employed in numerous recent studies [22-24,46,65-68].

The minimum allowable increment of water level increase for specific confidence levels was calculated using established methods [25]. Given the cumulative vertical uncertainty of $0.189 \mathrm{~m}$, a $15 \mathrm{in}$. $(1.25 \mathrm{ft}$, or $0.381 \mathrm{~m})$ increment can be mapped with $68 \%$ confidence, a $30 \mathrm{in}$. $(2.5 \mathrm{ft}$, or $0.762 \mathrm{~m})$ increment at $95 \%$ confidence, and a $45 \mathrm{in}$. (3.75 ft, or $1.143 \mathrm{~m})$ increment at $99 \%$ confidence. Note that English units are used here, and following, as those units are most commonly used in the Marshall Islands. For context on these increments of water level increase, consider the following: an increase in water level of $25.4 \mathrm{in}$. $(0.645 \mathrm{~m})$ would be the equivalent of LMSL moving up to the current high tide line (MHHW). Under such a scenario, and assuming the tidal range stays the same, an additional $9 \%$ of currently "dry" land (land currently above MHHW) would be subject to regular inundation by normal tides.

The three selected water levels $(1.25 \mathrm{ft}, 2.5 \mathrm{ft}$, and $3.75 \mathrm{ft}$, or $0.381 \mathrm{~m}, 0.762 \mathrm{~m}$, and $1.143 \mathrm{~m}$, respectively) were mapped using the three approaches described above. For comparison purposes, Table 2 displays the results of the vertical accuracy assessments of the other DEMs available for Majuro Atoll, as well as the corresponding minimum inundation increments. Additional information on the uncertainty of the DEMs is presented in Figures S1-S3 in the Supplementary Materials. As reflected in the values in Table 2, less accurate DEMs, even though the measured accuracies are better than product specifications (Table 1), do not allow high confidence mapping of small water level increases, and thus have little or no value for spatially explicit inundation exposure assessment of low-relief coastal settings like Majuro Atoll. 


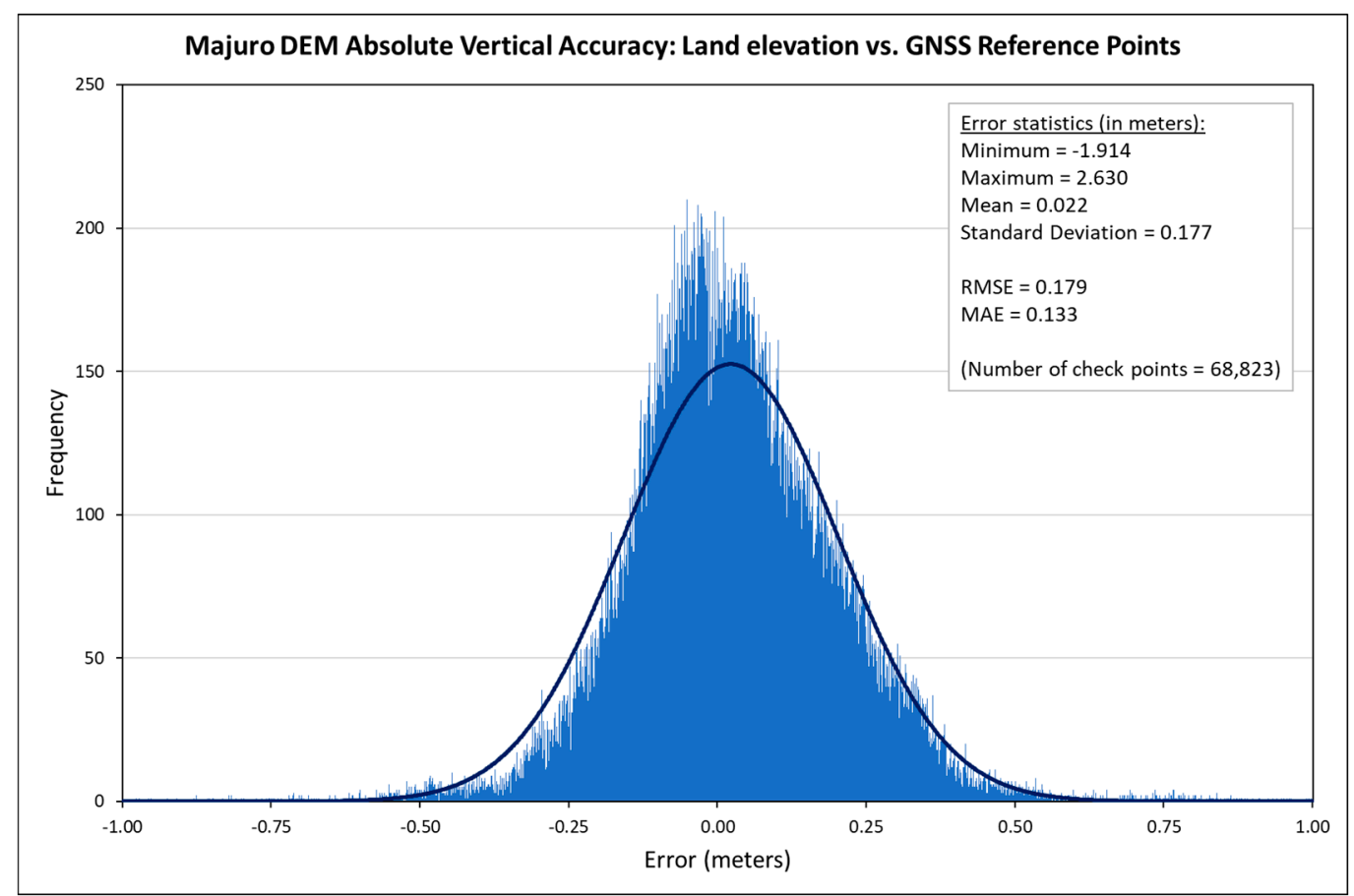

Figure 2. Elevation error characteristics of the Majuro Atoll UAS-SfM DEM for land areas above mean higher high water (MHHW). GNSS is Global Navigation Satellite System. RMSE is root mean square error. MAE is mean absolute error. The dark blue line is the normal distribution curve.

Table 2. Measured absolute vertical accuracies (expressed as RMSE) for Majuro Atoll DEMs and corresponding minimum inundation increments at $68 \%$ and $95 \%$ confidence. The mean error is also given, which can indicate an overall elevation bias in a DEM.

\begin{tabular}{ccccc}
\hline DEM & Mean Error (m) & $\begin{array}{c}\text { Measured } \\
\text { Accuracy } \\
\text { (RMSE in } \mathbf{~ m )}\end{array}$ & $\begin{array}{c}\text { Minimum } \\
\text { Increment (m) } \\
\mathbf{6 8 \%} \text { Confidence }\end{array}$ & $\begin{array}{c}\text { Minimum } \\
\text { Increment (m) }\end{array}$ \\
$\mathbf{9 5 \%}$ Confidence \\
\hline UAS-SfM & 0.022 & 0.179 & 0.357 & 0.700 \\
SRTM & 0.114 & 2.234 & 4.467 & 8.756 \\
ASTER GDEM & 5.170 & 6.136 & 12.272 & 24.054 \\
AW3D30 & -0.026 & 1.237 & 2.475 & 4.851 \\
TanDEM-X & -1.904 & 2.771 & 5.542 & 10.862 \\
DG-AES & -0.032 & 0.374 & 0.748 & 1.466 \\
\hline
\end{tabular}

\subsection{Inundation Maps}

Digital datasets delineating projected land areas exposed to inundation were produced with the three mapping approaches described above using the three specified water level increase scenarios $(1.25 \mathrm{ft}, 2.5 \mathrm{ft}$, and $3.75 \mathrm{ft}$, or $0.381 \mathrm{~m}, 0.762 \mathrm{~m}$, and $1.143 \mathrm{~m}$, respectively). ArcGIS was used to conduct the inundation exposure mapping, with much of the processing automated by Python scripting. The resulting datasets are freely available through a USGS data release [69].

\subsubsection{Hydrostatic Inundation}

Estimates of the area of Majuro Atoll (land area above MHHW) exposed to inundation in the different mapping approaches and water increase scenarios are presented in Tables 3 and 4 . The areas are presented as percent of the total land area above MHHW $\left(3.601 \mathrm{~m}^{2}\right.$, or $9.326 \mathrm{~km}^{2}$, for the study area portion of the atoll). Table 3 shows the results for the deterministic and modified deterministic mapping methods. Note that for the modified deterministic approach, a range is given, which reflects the 
minimum and maximum projected areas as mapped with the extremes of the full range of cumulative vertical error. Table 4 shows the results for the probabilistic mapping method with the likelihood categories of projected inundation also being labeled with the terminology used in Intergovernmental Panel on Climate Change (IPCC) assessment reports [70].

Table 3. Majuro Atoll areas exposed to inundation, expressed as percent of land area above MHHW (deterministic and modified deterministic mapping methods).

\begin{tabular}{|c|c|c|c|c|c|c|}
\hline \multirow{2}{*}{ Method } & \multicolumn{2}{|c|}{$1.25 \mathrm{ft}(0.381 \mathrm{~m})$} & \multicolumn{2}{|c|}{$2.5 \mathrm{ft}(0.762 \mathrm{~m})$} & \multicolumn{2}{|c|}{$3.75 \mathrm{ft}(1.143 \mathrm{~m})$} \\
\hline & $\begin{array}{c}\text { Marine } \\
\text { Inundation }\end{array}$ & $\begin{array}{c}\text { Low-Lying } \\
\text { Areas }\end{array}$ & $\begin{array}{c}\text { Marine } \\
\text { Inundation }\end{array}$ & $\begin{array}{c}\text { Low-Lying } \\
\text { Areas }\end{array}$ & $\begin{array}{c}\text { Marine } \\
\text { Inundation }\end{array}$ & $\begin{array}{c}\text { Low-Lying } \\
\text { Areas }\end{array}$ \\
\hline Deterministic & $4.50 \%$ & $1.92 \%$ & $13.03 \%$ & $5.42 \%$ & $41.27 \%$ & $0.79 \%$ \\
\hline $\begin{array}{l}\text { Modified } \\
\text { Deterministic } 68 \% \\
\text { confidence }\end{array}$ & $2.12-7.48 \%$ & $0.93-3.40 \%$ & $7.43-21.62 \%$ & $3.37-7.95 \%$ & $21.45-53.81 \%$ & $0.83-7.93 \%$ \\
\hline $\begin{array}{c}\text { Modified } \\
\text { Deterministic 95\% } \\
\text { confidence }\end{array}$ & $0.06-12.86 \%$ & $0.40-5.34 \%$ & $4.58-40.94 \%$ & $0.78-1.94 \%$ & $13.20-65.42 \%$ & $0.21-5.51 \%$ \\
\hline
\end{tabular}

Table 4. Majuro Atoll areas exposed to inundation, expressed as percent of land area above MHHW (probabilistic mapping method). IPCC is Intergovernmental Panel on Climate Change.

\begin{tabular}{ccccccc}
\hline \multirow{2}{*}{$\begin{array}{c}\text { Probability of } \\
\text { Inundation }\end{array}$} & \multicolumn{2}{c}{$\mathbf{1 . 2 5} \mathbf{f t}(\mathbf{0 . 3 8 1} \mathbf{~ m})$} & \multicolumn{2}{c}{$\mathbf{2 . 5} \mathbf{f t} \mathbf{( 0 . 7 6 2 ~ \mathbf { ~ m } )}$} & \multicolumn{2}{c}{$\mathbf{3 . 7 5} \mathbf{f t} \mathbf{( 1 . 1 4 3} \mathbf{~ m})$} \\
\cline { 2 - 6 } & $\begin{array}{c}\text { Marine } \\
\text { Inundation }\end{array}$ & $\begin{array}{c}\text { Low-Lying } \\
\text { Areas }\end{array}$ & $\begin{array}{c}\text { Marine } \\
\text { Inundation }\end{array}$ & $\begin{array}{c}\text { Low-Lying } \\
\text { Areas }\end{array}$ & $\begin{array}{c}\text { Marine } \\
\text { Inundation }\end{array}$ & $\begin{array}{c}\text { Low-Lying } \\
\text { Areas }\end{array}$ \\
\hline $\begin{array}{c}68 \% \text { chance (IPCC: } \\
\text { "Likely") }\end{array}$ & $3.13 \%$ & $1.17 \%$ & $9.46 \%$ & $3.90 \%$ & $33.62 \%$ & $0.43 \%$ \\
\hline $\begin{array}{c}95 \% \text { chance (IPCC: } \\
\text { "Extremely Likely") }\end{array}$ & $0.54 \%$ & $0.42 \%$ & $5.38 \%$ & $1.90 \%$ & $20.44 \%$ & $0.09 \%$ \\
\hline
\end{tabular}

The estimates of area exposed to inundation resulting from the deterministic mapping method have no indication of quality. The modified deterministic approach provides bounds for projected inundation with a corresponding confidence level that the true area falls somewhere within the stated range. However, the range can become large, especially at a higher water level (for instance see marine inundation of $3.75 \mathrm{ft}$, or $1.143 \mathrm{~m}$, at 95\% confidence), which may limit the usefulness of the estimate. For the results of the probabilistic approach, note how the estimated area generally tends to be much closer to the low end of the range of the corresponding modified deterministic results; for example, $9.46 \%$ for $2.5 \mathrm{ft}(0.762 \mathrm{~m})$ of marine inundation at $68 \%$ probability (Table 4$)$ compared to the modified deterministic range of $7.43-21.62 \%$ at $68 \%$ confidence. With the probabilistic approach, any probability of inundation (between $0 \%$ and $100 \%$ ) can be used; $68 \%$ and $95 \%$ are used here to match the confidence levels used in the modified deterministic approach. When comparing probabilistic results with corresponding deterministic results (same water level and same inundation type) (Tables 3 and 4), in all cases, the areas exposed to inundation are less for the probabilistic approach than the deterministic approach. Thus, in addition to results from deterministic mapping carrying no confidence level, the method consistently overpredicts the size of the area exposed to inundation.

Maps of example inundation areas help illustrate some of the effects of various mapping methods and confidence/probability levels. Figure 3 shows the location of detailed areas displayed in Figures 4-8. These four subsets are used to display results with sufficient detail for a variety of land use/land cover (dense urban development, infrastructure, rural). 


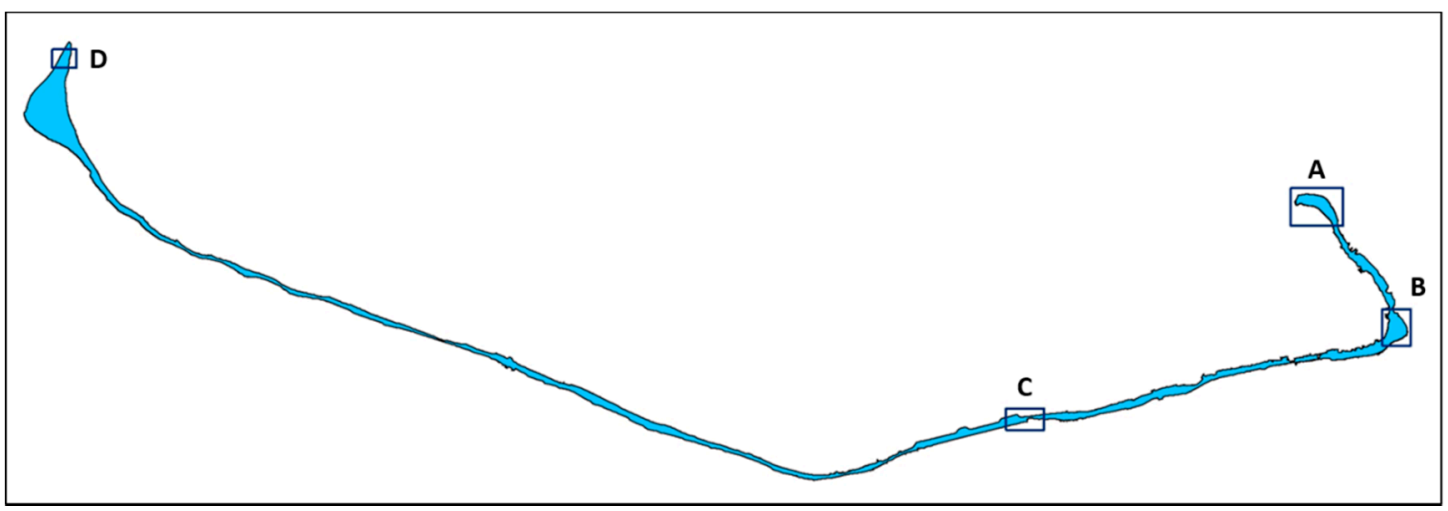

Figure 3. Location of detailed areas displayed in Figures 4-8 (subsets of the full study area).

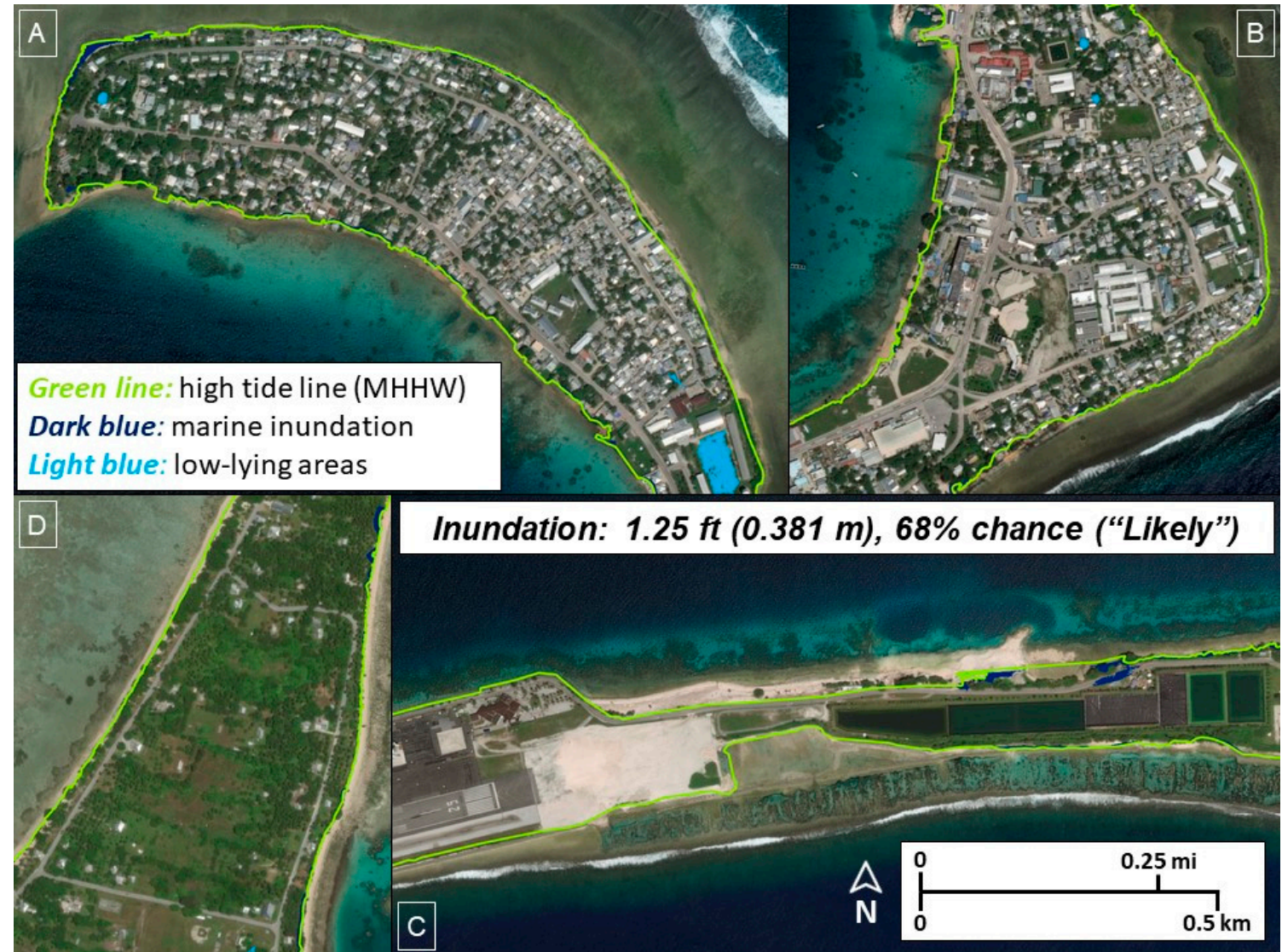

Figure 4. Results of probabilistic inundation mapping showing the areas with a $68 \%$ chance of inundation at the $1.25 \mathrm{ft}(0.381 \mathrm{~m})$ water level increase scenario. (A-D) are the detailed areas (subsets of the full study area) of Majuro Atoll as indicated in Figure 3. 


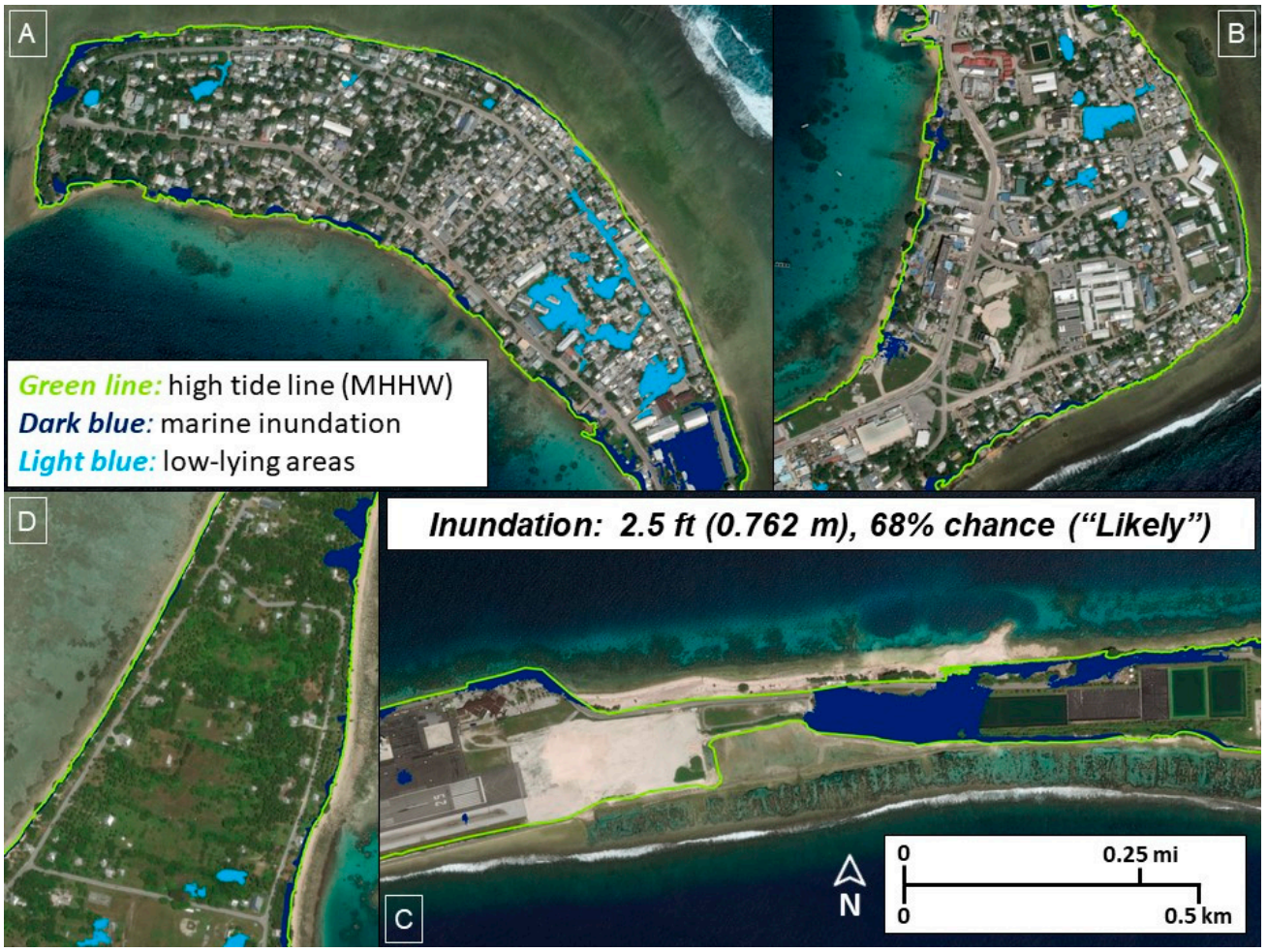

Figure 5. Results of probabilistic inundation mapping showing the areas with a $68 \%$ chance of inundation at the $2.5 \mathrm{ft}(0.762 \mathrm{~m})$ water level increase scenario. (A-D) are the detailed areas (subsets of the full study area) of Majuro Atoll as indicated in Figure 3.

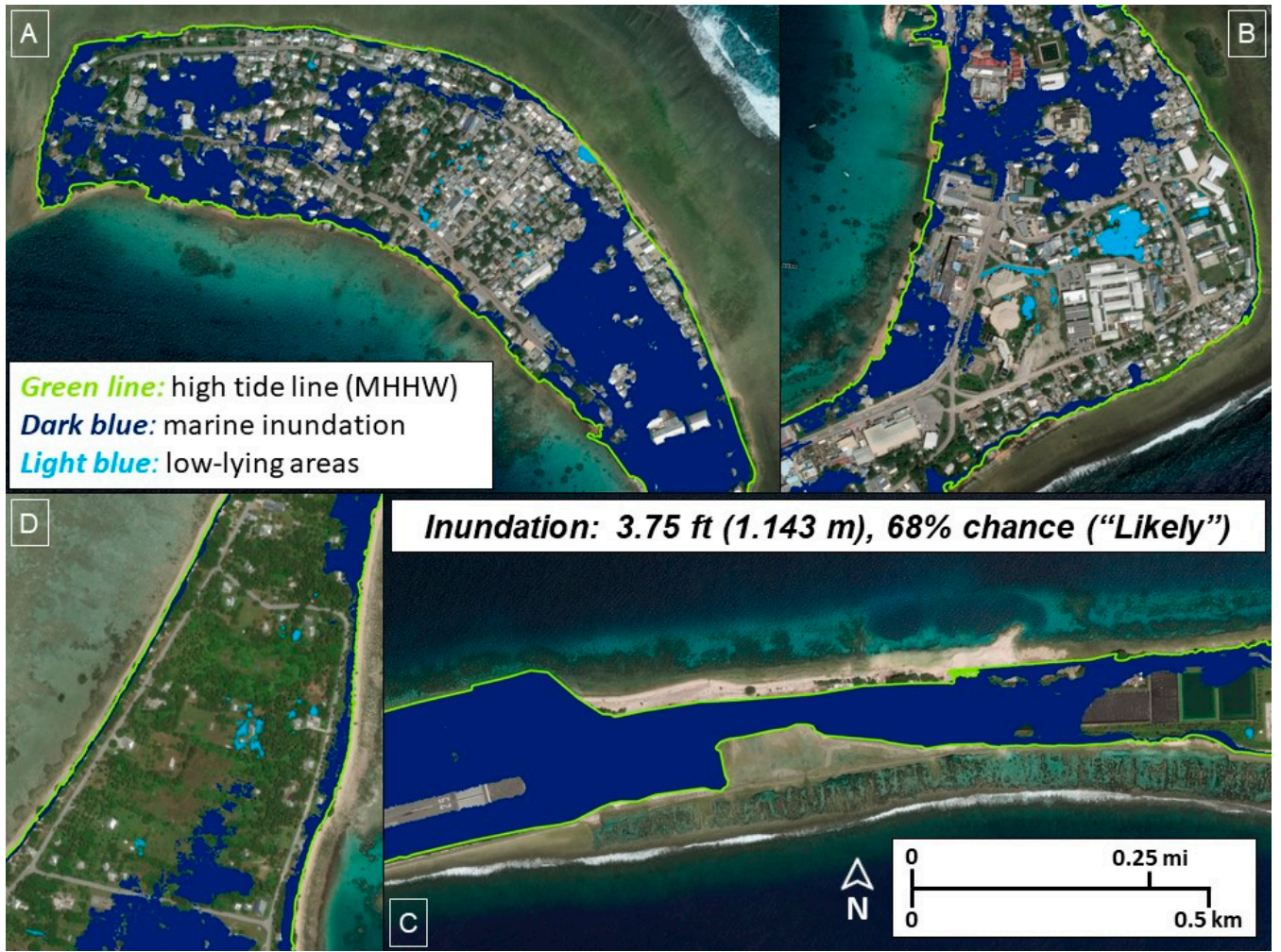

Figure 6. Results of probabilistic inundation mapping showing the areas with a $68 \%$ chance of inundation at the $3.75 \mathrm{ft}(1.143 \mathrm{~m})$ water level increase scenario. (A-D) are the detailed areas (subsets of the full study area) of Majuro Atoll as indicated in Figure 3. 


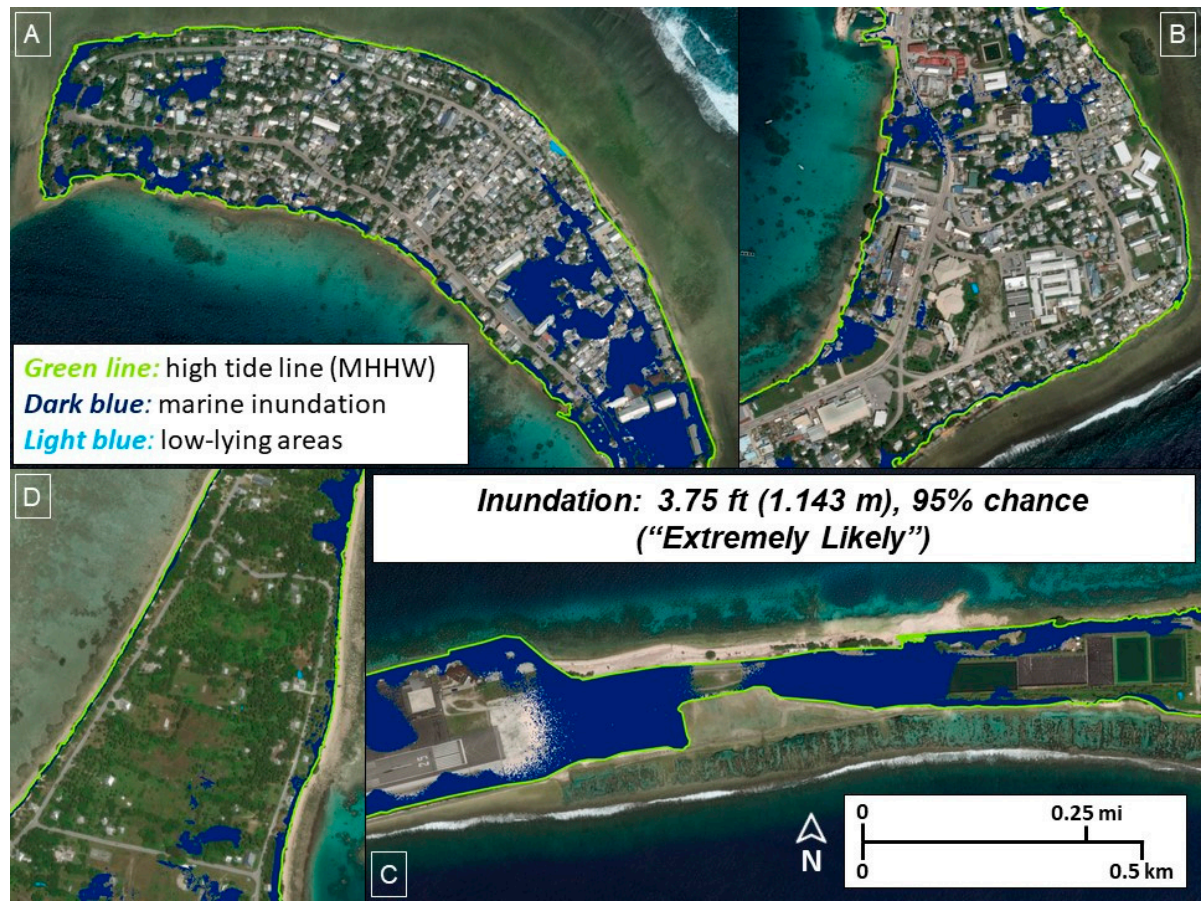

Figure 7. Results of probabilistic inundation mapping showing the areas with a $95 \%$ chance of inundation at the $3.75 \mathrm{ft}(1.143 \mathrm{~m})$ water level increase scenario. (A-D) are the detailed areas (subsets of the full study area) of Majuro Atoll as indicated in Figure 3.

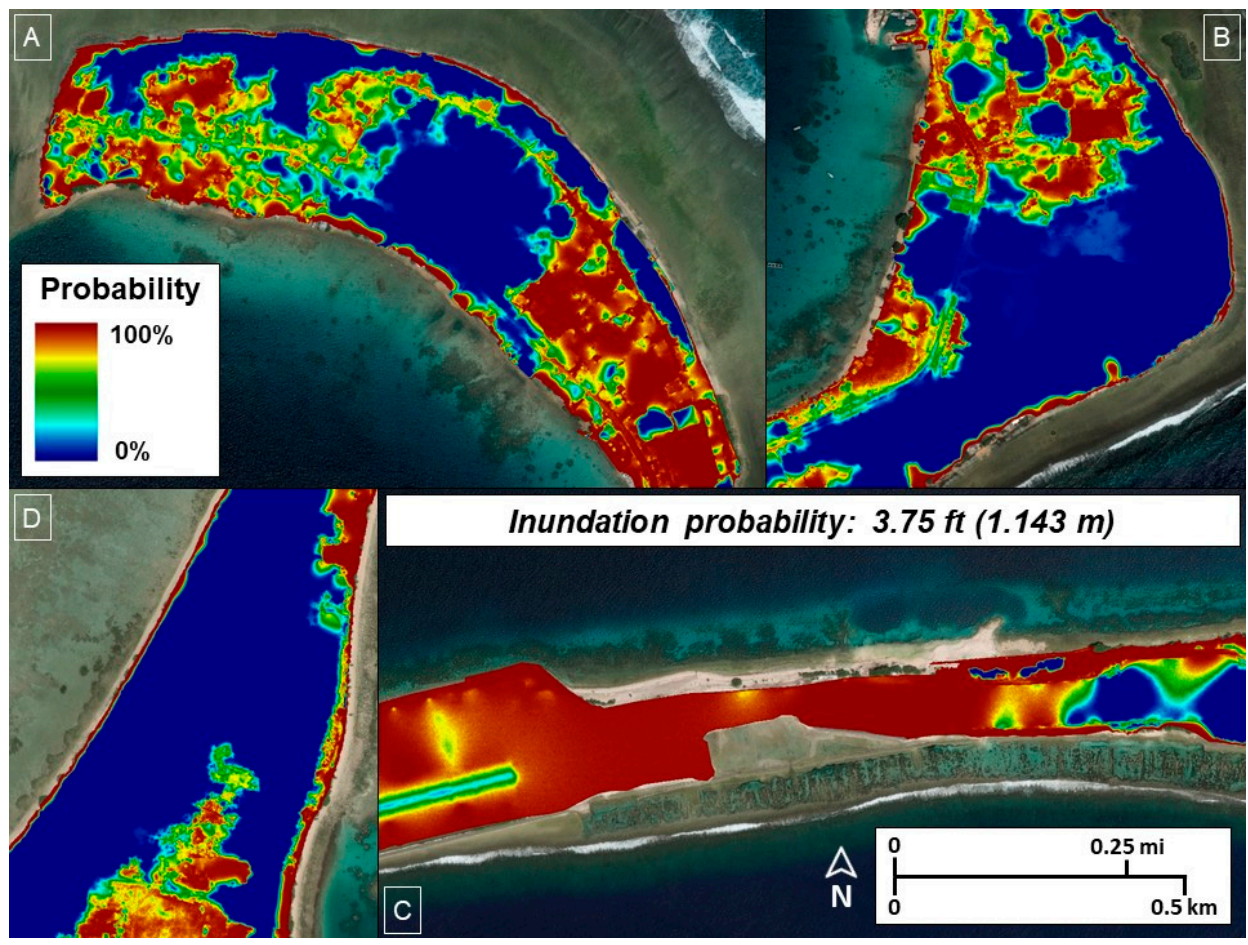

Figure 8. The input dataset for probabilistic inundation mapping, which is derived from spatial error propagation through Monte Carlo simulation. The probability of inundation at any location for a given water level increase is simply the count of the number of times the location was included in the inundation mask divided by the number of realizations ( 750 for this study). Figures 6 and 7 were derived from the continuous variable (inundation probability) grid by applying different probability thresholds (68\% and 95\% for Figures 6 and 7, respectively). (A-D) are the detailed areas (subsets of the full study area) of Majuro Atoll as indicated in Figure 3. 
Figures 4-6 show the progression of projected areas exposed to inundation as the water level increases through the three scenarios (when mapping method and probability are held constant). Note that not only do the exposed areas increase, as would be expected, but also low-lying areas are "converted" to marine inundation areas as water level increases. At higher water levels, a direct hydrologic connection to the ocean becomes available, a connection that is not present at lower water levels. The percent of low-lying area converted to marine inundation at the next higher water level was calculated for all the mapping methods. Generally, about $10-15 \%$ of the low-lying area becomes marine inundation when increasing from $1.25 \mathrm{ft}(0.381 \mathrm{~m})$ to $2.5 \mathrm{ft}(0.762 \mathrm{~m})$. More than $95 \%$ of low-lying areas convert to marine inundation when increasing water level from $2.5 \mathrm{ft}(0.762 \mathrm{~m})$ to $3.75 \mathrm{ft}(1.143 \mathrm{~m})$, which is likely a reflection of the overall low-relief nature of the atoll land.

Comparison of Figures 6 and 7 shows the effect of portraying different chances of inundation from the probabilistic mapping products. In this case, the projected area exposed to inundation decreases when thresholding the inundation probability grid (Figure 8 ) at $68 \%$ probability (33.62\% of land, from Table 4 ) and then $95 \%$ probability (20.44\% of land, from Table 4$)$. The areas that remain in the projected inundation exposure are those that are at an elevation range below the specified water level even when cumulative vertical uncertainty of the DEM is factored in, while the areas that are removed by changing the probability threshold are high enough even when the error is included.

The source of marine inundation, either the lagoon-facing shore or the open ocean-facing shore, has also been identified through spatial processing. Such a distinction can be important for mitigation planning as differences in the character of the two types of shorelines have been identified [3] and both sources of inundation have been observed multiple times [18]. The elevation of the lagoon shoreline is generally lower, and it is less armored than the ocean-facing shoreline [18]. The results of marine inundation mapping distinguished by source support the previously identified differing shoreline characteristics. Of the 21 instances of marine inundation delineation (across all methods, water level increases, and confidence levels/probabilities), more than three-quarters (16 of 21) showed that lagoon inundation contributed a greater percent of the total marine inundation than did ocean inundation. In the five cases where the portion of ocean shore inundation exceeded lagoon inundation, three were at the highest water level $(3.75 \mathrm{ft}$, or $1.143 \mathrm{~m})$ and two at the $2.5 \mathrm{ft}(0.762 \mathrm{~m})$ water level. Also important are those cases where certain areas were identified as being exposed to marine inundation from both the lagoon-facing shore and the ocean-facing shore. The percentage of the total marine inundation that was included in both lagoon and ocean inundation was calculated for all delineations, and in all cases that percentage increased with increasing water level, which would be expected. The actual percentage varied according to mapping method and confidence level/probability. However, for any given instance of marine inundation delineation, these "combined" lagoon and ocean inundation areas are important because they reflect a greater degree of exposure. These areas are indicative of the narrow width of the land (and low relief) at specific locations along the atoll.

\subsubsection{Event-Based Inundation}

Many coastal inundation exposure assessments are aimed toward analysis of long-term, gradual changes along the shore because of sea-level rise. However, fast onset changes also can have substantial impacts on populations and resources in coastal environments. There have been discussions on the use of the terms for temporary conditions when dry areas become wet, either periodically or episodically, ("flooding") and permanent conditions of submergence ("inundation") [71]. Regardless of the terminology used, the concepts (for example, minimum increment of water level increase) and mapping methods described in this study are applicable to both gradual and fast onset water level increases. Figure 9 shows the results of an analysis of a projected water level increase event, in this case wave run-up, on the densely populated eastern end of Majuro Atoll. Wave run-up forecasts are routinely generated for Majuro and other islands by the Pacific Islands Ocean Observing System (PacIOOS) [72]. The projected area subject to wave run-up was mapped with the deterministic and probabilistic methods, and the results demonstrate the increased information from the probabilistic 
approach. The deterministic method projected $43.40 \%$ of the forecast zone to be subject to impacts of the wave run-up, but this number has no quality information (confidence level or probability) associated with it. The probabilistic method delineated an area of $31.73 \%$ of the forecast zone with a $68 \%$ chance of flooding (Figure 9), and a projected area of $17.26 \%$ of land in the forecast zone having a $95 \%$ chance of flooding. Accounting for vertical uncertainty in the underlying elevation data used for spatial projections of such inundation events improves the flexibility and quality of the mapped information.

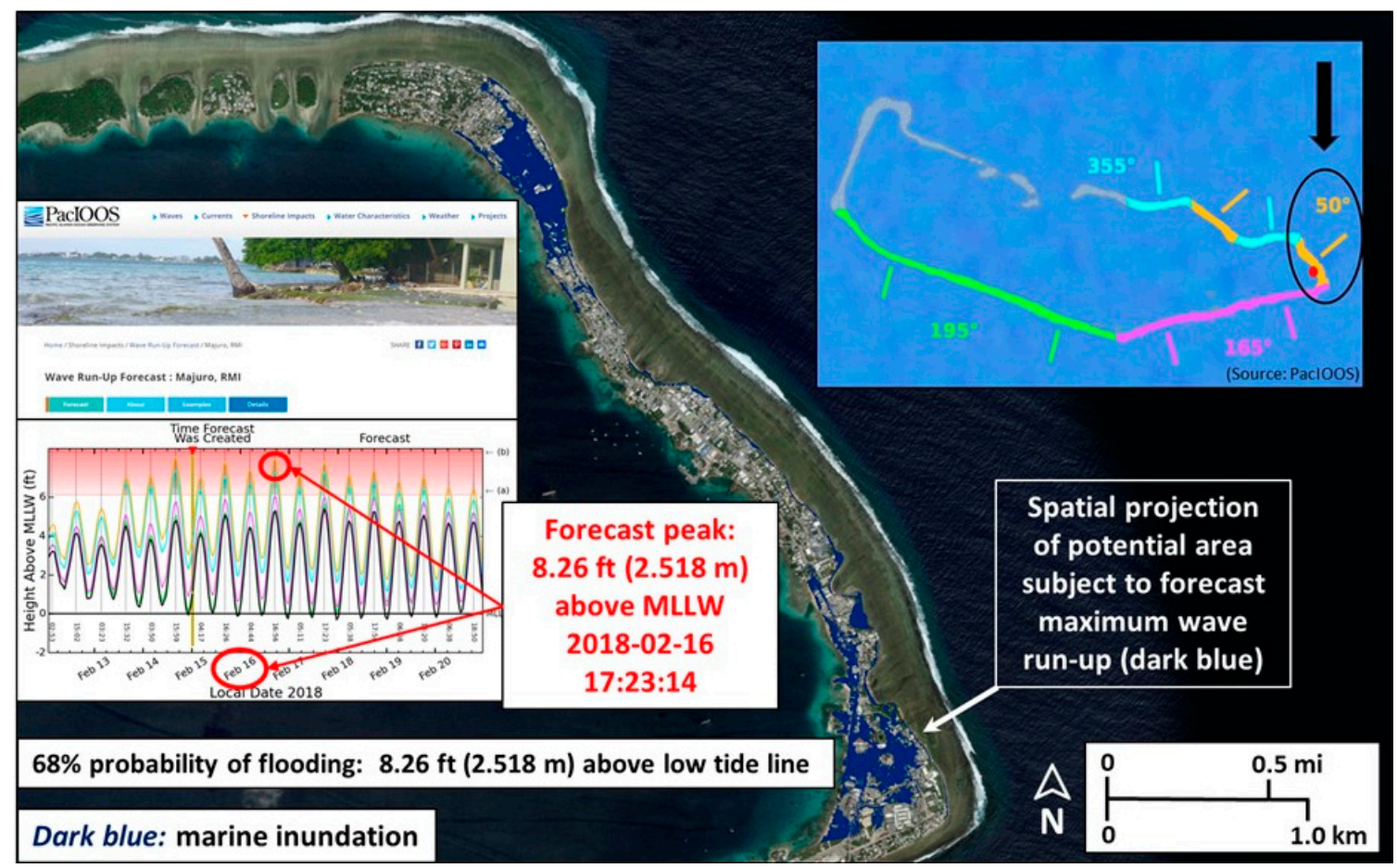

Figure 9. Results of a demonstration of probabilistic mapping of an inundation event (run-up of high waves from a seaward angle of 50 degrees) on the eastern end of Majuro Atoll. The wave run-up forecast is from a Pacific Islands Ocean Observing System (PacIOOS) web page (left center) for the forecast zone of the eastern portion of Majuro Atoll (upper right). The map shows the areas with a $68 \%$ chance of being impacted by the specified forecast peak run-up $(8.26 \mathrm{ft}$, or $2.518 \mathrm{~m}$, above mean lower low water [MLLW], which is equivalent to $4.12 \mathrm{ft}$, or $1.256 \mathrm{~m}$, above MHHW).

\section{Discussion}

\subsection{The Use of High-Accuracy Elevation Data for Coastal Assessments}

The use of a high-resolution, high-accuracy DEM for coastal inundation exposure assessment has clear advantages, especially for a low-relief setting like Majuro Atoll, where the average elevation is less than $2 \mathrm{~m}$ above sea level [13]. Using a high-accuracy elevation dataset like the UAS-SfM DEM employed in this study, with a vertical uncertainty of better than $20 \mathrm{~cm}$ RMSE, allows modeling and projection of inundation with fine increments of water level increase at high confidence levels. Conversely, the use of global elevation models, which have been widely employed in such coastal assessments, leads to results with very low confidence [25]. SRTM in particular has been extensively used for coastal assessments [25], including studies that focus on island environments [9,10]. Often these studies use sea-level rise increments on the order of 1 or $2 \mathrm{~m}$, which are well within the vertical error bounds of the SRTM DEM (Table 2). The use of such DEMs for inundation assessment is especially flawed for low-relief settings like Majuro Atoll, where the average land elevation is less than the inherent vertical uncertainty of SRTM: $1.80 \mathrm{~m}$ average elevation [13] versus 2.23 m RMSE (Table 2). Thus, the veracity of results is called into question for studies that project substantial island land 
loss (and corresponding impacts like displacement of populations) $[9,10]$ from climate change-related sea-level rise.

Testing with SRTM data for inundation mapping over Majuro Atoll confirms the severe limitations of such global DEMs. SRTM data were used in deterministic and modified deterministic approaches and the results, which reflect the characteristics of SRTM data, are very different than those derived from the UAS-SfM high-accuracy DEM. The deterministic results are the same for all three water level increase scenarios (3.60\% of land above MHHW for marine inundation, and $0.90 \%$ of land for low-lying areas). These results reflect the fact that elevation values in the SRTM DEM are quantized to $1 \mathrm{~m}$, while the water level intervals used are specified to the millimeter, and also that the SRTM data have a spatial resolution of about $30 \mathrm{~m}$, thus limiting the detail of the shoreline that can be portrayed. The modified deterministic results with SRTM show a bit more variability than the deterministic results across the three water levels, but the projected areas are still much smaller than corresponding results from the UAS-SfM DEM. Some of the other DEMs available for Majuro have better vertical accuracy than SRTM, especially the DG-AES DEM (Table 2), but none are accurate enough to allow for use in modeling inundation increments on the order of a foot $(0.3048 \mathrm{~m})$ as can be done with the UAS-SfM DEM.

\subsection{Implications of Results for Vulnerability Assessments}

Accounting for vertical uncertainty is advantageous for the use of inundation exposure mapping in vulnerability assessments. Many elevation-based assessments of inundation or coastal flooding exposure have not considered the inherent vertical uncertainty, and users of such assessment results have no indication of the quality associated with the products and findings [25]. The comparison of the different inundation mapping methods documented here shows that the probabilistic approach handles vertical uncertainty most rigorously and provides the most flexibility in the use of output products (selectable probability levels for maps or statistics of areas exposed to inundation). However, the probabilistic approach does require access to sufficient computer resources for error propagation through Monte Carlo simulation, especially if input data have high spatial resolution, the study area is large, and multiple inundation scenarios are to be modeled. If probabilistic mapping is not practical or possible, then the modified deterministic approach is preferred, as it accounts for vertical uncertainty by bounding the elevation error and allows for presenting results with a specified confidence level. The simple deterministic method does not include any consideration of vertical uncertainty and therefore is not the best approach for use in inundation exposure assessments.

For areas included in the inundation exposure zone (by any of the methods), the DEM and specified water level can be used to generate a map of flood depth. Such a map may be especially important for projections of event-based inundation (see Section 3.2.2), where it could be advantageous to show the varying severity of the hazard according to location.

The delineations of areas exposed to inundation in this assessment of Majuro Atoll are restricted to modeling of hydrostatic inundation, otherwise termed still water or flat water inundation. The projected impact zones do not include the effects of dynamic coastal processes, such as wave run-up, coastal erosion, sediment accretion, storms, and groundwater hydrodynamics. Recent research results clearly show that inclusion of these factors is critical for highly accurate estimates of exposed area, population, and resources $[8,73,74]$. Until such factors can be added to an inundation exposure assessment, the current results represent the initial spatially accurate delineation of areas vulnerable to sea-level rise and coastal flooding events.

\subsection{Limitations and Caveats for the Use of Results}

In addition to the limitation of hydrostatic modeling and exclusion of dynamic coastal processes, there are other known limiting factors for the assessment results. The UAS-SfM DEM used as the basis for inundation modeling has high vertical accuracy overall, but the accuracy does vary spatially primarily due to the presence of surface features, namely built structures and vegetation. The SfM process used to develop the DEM uses a point cloud derived from stereoscopic imagery, and if the 
ground is not captured in the images then the point cloud, and subsequent DEM, will not include direct measurements of the ground elevation. In these cases, the ground elevations are interpolated based on nearby ground points, but in areas of dense vegetation (for instance, coconut trees) and large buildings the vertical accuracy can be degraded. In a low-relief setting like Majuro, where small changes in slope can affect water flow, these interpolated areas may not capture local land surface configuration as accurately as other areas where the UAS images captured the ground directly.

Additionally, not all flood protection barriers (seawalls, rip-rap) and drainage modifications that can affect water flow (ditches, culverts) are accurately portrayed in the DEM. Future improvements to the DEM used for inundation modeling should include addition of these features. Terrestrial, or ground-based, lidar (light detection and ranging) scanning is a useful source of high-resolution, high-accuracy elevation data that can be used to acquire these critical features for integration into an enhanced DEM $[23,68,75]$.

The projected areas subject to inundation may be conservative (less extensive than actual conditions) due to the way in which local sea level datums were applied to the elevation model. As described previously, prior to inundation mapping the DEM was transformed to orthometric (mean sea level referenced) elevations from its native ellipsoid referenced vertical coordinates through application of a local geoid model. The geoid model was constructed from a local network of leveled benchmarks, which are tied to LMSL through a tidal benchmark for the Majuro tide gauge. The orthometric height of that tidal benchmark references LMSL as defined by tide records recorded in 1968-1969 [64]. However, as with many tide gauge locations, there is a rising trend in LMSL at the Majuro gauge [76], and LMSL is now about 7 in. $(0.178 \mathrm{~m})$ higher than it was in 1969 when the orthometric elevation reference for the leveled benchmarks was established. Thus, the local geoid used to apply orthometric height referencing to the DEM represents a lower LMSL than current conditions. The net effect is that the DEM is slightly lower relative to current LMSL; therefore, any inundation area projections also are lower, in a vertical sense, on the landscape. One simple test was conducted to check the type of effects possible on inundated area projections. Using $2.5 \mathrm{ft}(0.762 \mathrm{~m})$ of marine inundation in the modified deterministic method (minimum extent) resulted in an increase of $13 \%$ in exposed land area when incorporating an increase of nearly 7 inches $(0.178 \mathrm{~m})$ to LMSL. Updating of the LMSL referencing of the DEM is a future enhancement to be considered.

The increased water levels used in this study $(1.25 \mathrm{ft}, 2.5 \mathrm{ft}$, and $3.75 \mathrm{ft}$, or $0.381 \mathrm{~m}, 0.762 \mathrm{~m}$, and $1.143 \mathrm{~m}$, respectively) do not have a specific date associated with them in the context of sea-level rise rates, but rather are plausible increases that help illustrate potential impacts to aid in mitigation planning. The current mean sea level trend at the Majuro tide station is $3.60 \mathrm{~mm} / \mathrm{yr}$ [76], which is close to the global mean sea level trend and equates to a change of $1.18 \mathrm{ft}(0.360 \mathrm{~m})$ in 100 years. However, projections of sea-level rise in the second half of the century show accelerated rates across the equatorial Pacific Ocean $[15,16]$, and so the higher increments may be realized by 2100 due primarily to contributions from Antarctica ice melt [77].

\section{Conclusions}

Like many other low-lying oceanic islands, Majuro Atoll is vulnerable to coastal inundation, whether the source of increased water levels is sea-level rise or fast onset events. Coarse-scale vulnerability assessments that include these islands have been conducted, but the results are severely limited for use in local-scale planning. Detailed information on the topography is critical for assessing coastal inundation exposure, but the lack of appropriate elevation data is often a constraint for many studies. A high-resolution, high-accuracy DEM derived from UAS imagery using SfM techniques has proven useful for conducting a first ever detailed, spatially explicit quantitative inundation exposure assessment for Majuro Atoll, RMI. The high vertical accuracy afforded by the DEM is especially important for a low-relief setting like Majuro Atoll, where a relatively small increase in coastal water level can have large effects. 
While the DEM used for this assessment does have high vertical accuracy, it still carries vertical uncertainty, as all elevation datasets do, and the most effective mapping methods rigorously account for that uncertainty. By properly considering the inherent vertical uncertainty, the inundation modeling results are expressed with specified confidence levels or probabilities that provide the user with data quality information. For this study, the probabilistic mapping approach provided results with the most flexibility (for example, selectable risk levels). For the middle of three water levels modeled, 2.5 $\mathrm{ft}(0.762 \mathrm{~m})$, an amount of sea-level rise quite plausible by the end of the current century, more than $13 \%$ of the atoll study area has a $68 \%$ chance of being exposed to the effects of coastal inundation. In IPCC terms, the inundation of this area is "Likely." At $95 \%$ chance of inundation, or what IPCC calls "Extremely likely," more than 7\% of the atoll study area will be exposed. At the highest water level modeled, $3.75 \mathrm{ft}(1.143 \mathrm{~m})$, more than $34 \%$ of the atoll study area is likely to be exposed to inundation (68\% chance or greater), while more than $20 \%$ of the atoll is extremely likely to be exposed (95\% chance or greater).

Atolls are subject to multiple threats from increasing coastal water levels [1], and these highly dynamic landforms [4] require detailed topographic mapping, and subsequent monitoring, so that geomorphic changes can be understood in the context of sea-level rise to inform adaptation planning [78]. To meet the critical need for detailed, high-accuracy elevation information required for coastal assessments, the UAS approach used to develop the DEM employed in this study is an appealing, cost-effective alternative to manned airborne systems that can have significant logistical challenges operating in remote, isolated locations [13]. Also, UAS and associated SfM methods are technologies that can be effectively acquired and employed by local entities in the island communities that need improved mapping for adaptation planning.

Supplementary Materials: The following are available online at http://www.mdpi.com/2072-4292/12/1/154/s1. Figure S1: Accuracy information for the UAS-SfM and DG-AES DEMs presented as violin plots. Figure S2: Accuracy information for the AW3D30 and SRTM DEMs presented as violin plots. Figure S3: Accuracy information for the TanDEM-X and ASTER GDEM DEMs presented as violin plots.

Author Contributions: Conceptualization, D.G., C.F., J.D., and M.P.-L.; Methodology, D.G., M.P.-L., J.D., C.F., M.B., M.K., and A.J.; Software, J.D., D.G., and M.P.-L.; Validation, D.G., M.P.-L., and J.D.; Formal Analysis, D.G., M.P.-L., and C.F.; Investigation, D.G., J.D., and M.P.-L.; Data Curation, J.D., D.G., M.K., and A.J.; Writing-Original Draft Preparation, D.G.; Writing-Review and Editing, D.G., M.P.-L., J.D., C.F., M.K., M.B., and A.J.; Visualization, D.G. and M.P.-L.; Project Administration, J.D., and D.G..; Funding Acquisition, C.F., J.D., and D.G. All authors have read and agreed to the published version of the manuscript.

Funding: Funding for this research was provided by the U.S. Department of the Interior Pacific Islands Climate Adaptation Science Center (PI-CASC), and the Land Change Science Program and Coastal-Marine Hazards and Resources Program of the U.S. Geological Survey.

Acknowledgments: The authors thank the following people for their contributions: Cindy Thatcher (USGS) and Tom Adamson (KBR, contractor to USGS) for valuable comments on an earlier version of the manuscript; Sandra Poppenga (USGS) for review of data products and metadata; Ed Carlson (NGS) and Ross Winans (NOAA) for developing the local geoid model for Majuro and associated uncertainty information; RMI Division of Lands and Survey for support in field work and data collection; Tony Kimmet (NRCS) for working with DigitalGlobe to provide the AES DEM; David Helweg (USGS) for encouragement and support in initiating and conducting this work. TanDEM-X data (C) DLR 2017) were provided by the German Aerospace Center (DLR) through the TanDEM-X Digital Elevation Model Announcement of Opportunity (Proposal ID: DEM_HYDR1176). Any use of trade, firm, or product names is for descriptive purposes only and does not imply endorsement by the U.S. Government.

Conflicts of Interest: The authors declare no conflict of interest. The funders had no role in the design of the study; in the collection, analyses, or interpretation of data; in the writing of the manuscript, or in the decision to publish the results.

\section{References}

1. Woodroffe, C.D. Reef-island topography and the vulnerability of atolls to sea-level rise. Glob. Planet. Chang. 2008, 62, 77-96. [CrossRef]

2. Holthus, P.; Crawford, M.; Makroro, C.; Sullivan, S. Vulnerability Assessment of Accelerated Sea Level Rise-Case Study: Majuro Atoll, Marshall Islands; South Pacific Regional Environment Programme: Apia, Samoa, 1992. 
3. Ford, M. Shoreline Changes on an Urban Atoll in the Central Pacific Ocean: Majuro Atoll, Marshall Islands. J. Coast. Res. 2012, 279, 11-22. [CrossRef]

4. Ford, M.R.; Kench, P.S. Multi-decadal shoreline changes in response to sea level rise in the Marshall Islands. Anthropocene 2015, 11, 14-24. [CrossRef]

5. Storlazzi, C.D.; Elias, E.P.; Berkowitz, P. Many Atolls May be Uninhabitable Within Decades Due to Climate Change. Sci. Rep. 2015, 5, 14546. [CrossRef] [PubMed]

6. Owen, S.D.; Kench, P.S.; Ford, M. Improving understanding of the spatial dimensions of biophysical change in atoll island countries and implications for island communities: A Marshall Islands' case study. Appl. Geogr. 2016, 72, 55-64. [CrossRef]

7. Kench, P.S.; Ford, M.R.; Owen, S.D. Patterns of island change and persistence offer alternate adaptation pathways for atoll nations. Nat. Commun. 2018, 9, 605. [CrossRef] [PubMed]

8. Storlazzi, C.D.; Gingerich, S.B.; Van Dongeren, A.; Cheriton, O.M.; Swarzenski, P.W.; Quataert, E.; Voss, C.I.; Field, D.W.; Annamalai, H.; Piniak, G.A.; et al. Most atolls will be uninhabitable by the mid-21st century because of sea-level rise exacerbating wave-driven flooding. Sci. Adv. 2018, 4, eaap9741. [CrossRef]

9. Wetzel, F.T.; Kissling, W.D.; Beissmann, H.; Penn, D.J. Future climate change driven sea-level rise: Secondary consequences from human displacement for island biodiversity. Glob. Chang. Biol. 2012, 18, 2707-2719. [CrossRef]

10. Bellard, C.; Leclerc, C.; Courchamp, F. Impact of sea level rise on the 10 insular biodiversity hotspots. Glob. Ecol. Biogeogr. 2014, 23, 203-212. [CrossRef]

11. Bevacqua, A.; Yu, D.; Zhang, Y. Coastal vulnerability: Evolving concepts in understanding vulnerable people and places. Environ. Sci. Policy 2018, 82, 19-29. [CrossRef]

12. Helweg, D.; Nash, S.A.B.; Polhemus, D.A. The Pacific Islands Climate Science Center Five-Year Science Agenda, 2014-2018; U.S. Geological Survey Open-File Report 2014-1075; U.S. Geological Survey: Reston, VA, USA, 2014. [CrossRef]

13. Palaseanu-Lovejoy, M.; Poppenga, S.K.; Danielson, J.J.; Tyler, D.J.; Gesch, D.B.; Kottermair, M.; Andrea, J.; Edward, C.; Thatcher, C.A.; Barbee, M.M. One-Meter Topobathymetric Digital Elevation Model. for Majuro Atoll, Republic of the Marshall Islands, 1944 to 2016; U.S. Geological Survey Scientific Investigations Report 2018-5047; U.S. Geological Survey: Reston, VA, USA, 2018. [CrossRef]

14. Storlazzi, C.D. Challenges of forecasting flooding on coral reef-lined coasts. Eos 2018, 99. [CrossRef]

15. Spada, G.; Bamber, J.L.; Hurkmans, R.T.W.L. The gravitationally consistent sea-level fingerprint of future terrestrial ice loss. Geophys. Res. Lett. 2013, 40, 482-486. [CrossRef]

16. Slangen, A.B.A.; Carson, M.; Katsman, C.A.; van de Wal, R.S.W.; Köhl, A.; Vermeersen, L.L.A.; Stammer, D. Projecting twenty-first century regional sea-level changes. Clim. Chang. 2014, 124, 317-332. [CrossRef]

17. Hoeke, R.K.; McInnes, K.L.; Kruger, J.C.; McNaught, R.J.; Hunter, J.R.; Smithers, S.G. Widespread inundation of Pacific islands triggered by distant-source wind-waves. Glob. Planet. Chang. 2013, 108, 128-138. [CrossRef]

18. Ford, M.; Merrifield, M.A.; Becker, J.M. Inundation of a low-lying urban atoll island: Majuro, Marshall Islands. Nat. Hazards 2018, 91, 1273-1297. [CrossRef]

19. Terry, J.P.; Chui, T.F.M. Evaluating the fate of freshwater lenses on atoll islands after eustatic sea-level rise and cyclone-driven inundation: A modelling approach. Glob. Planet. Chang. 2012, 88-89, 76-84. [CrossRef]

20. Gesch, D.B. Analysis of Lidar Elevation Data for Improved Identification and Delineation of Lands Vulnerable to Sea-Level Rise. J. Coast. Res. 2009, 10053, 49-58. [CrossRef]

21. Cooper, H.M.; Chen, Q. Incorporating uncertainty of future sea-level rise estimates into vulnerability assessment: A case study in Kahului, Maui. Clim. Chang. 2013, 121, 635-647. [CrossRef]

22. Cooper, H.M.; Fletcher, C.H.; Chen, Q.; Barbee, M.M. Sea-level rise vulnerability mapping for adaptation decisions using LiDAR DEMs. Prog. Phys. Geogr. 2013, 37, 745-766. [CrossRef]

23. Gesch, D.B. Consideration of Vertical Uncertainty in Elevation-Based Sea-Level Rise Assessments: Mobile Bay, Alabama Case Study. J. Coast. Res. 2013, 63, 197-210. [CrossRef]

24. Schmid, K.; Hadley, B.; Waters, K. Mapping and Portraying Inundation Uncertainty of Bathtub-Type Models. J. Coast. Res. 2014, 295, 548-561. [CrossRef]

25. Gesch, D.B. Best Practices for Elevation-Based Assessments of Sea-Level Rise and Coastal Flooding Exposure. Front. Earth Sci. 2018, 6. [CrossRef]

26. West, H.; Horswell, M.; Quinn, N. Exploring the sensitivity of coastal inundation modelling to DEM vertical error. Int. J. Geogr. Inf. Sci. 2018, 32, 1172-1193. [CrossRef] 
27. Farr, T.G.; Rosen, P.A.; Caro, E.; Crippen, R.; Duren, R.; Hensley, S.; Kobrick, M.; Paller, M.; Rodriguez, E.; Roth, L.; et al. The Shuttle Radar Topography Mission. Rev. Geophys. 2007, 45. [CrossRef]

28. Abrams, M.; Bailey, B.; Tsu, H.; Hato, M. The ASTER Global DEM. Photogramm. Eng. Remote Sens. 2010, 76, 344-348.

29. Tadono, T.; Nagai, H.; Ishida, H.; Oda, F.; Naito, S.; Minakawa, K.; Iwamoto, H. Generation of the 30 M-Mesh Global Digital Surface Model by ALOS PRISM. ISPRS Int. Arch. Photogramm. Remote Sens. Spat. Inf. Sci. 2016, XLI-B4, 157-162. [CrossRef]

30. Zink, M.; Bachmann, M.; Brautigam, B.; Fritz, T.; Hajnsek, I.; Moreira, A.; Wessel, B.; Krieger, G. TanDEM-X: The New Global DEM Takes Shape. IEEE Geosci. Remote Sens. Mag. 2014, 2, 8-23. [CrossRef]

31. Digital Globe Advanced Elevation Suite. Available online: www.digitalglobe.com/products/advancedelevation-suite (accessed on 9 August 2019).

32. Grohmann, C.H. Evaluation of TanDEM-X DEMs on selected Brazilian sites: Comparison with SRTM, ASTER GDEM and ALOS AW3D30. Remote Sens. Environ. 2018, 212, 121-133. [CrossRef]

33. Australian Government Bureau of Meteorology. Pacific Sea Level and Geodetic Monitoring Project. Available online: www.bom.gov.au/pacific/projects/pslm/ (accessed on 9 August 2019).

34. Holgate, S.J.; Matthews, A.; Woodworth, P.L.; Rickards, L.J.; Tamisiea, M.E.; Bradshaw, E.; Foden, P.R.; Gordon, K.M.; Jevrejeva, S.; Pugh, J. New Data Systems and Products at the Permanent Service for Mean Sea Level. J. Coast. Res. 2013, 29, 493-504. [CrossRef]

35. NOAA. Technical Considerations for Use of Geospatial Data in Sea Level Change Mapping and Assessment; National Oceanic and Atmospheric Administration Technical Report NOS 2010-01; NOAA: Silver Spring, MD, USA, 2010; p. 130.

36. Habel, S.; Fletcher, C.H.; Rotzoll, K.; El-Kadi, A.I. Development of a model to simulate groundwater inundation induced by sea-level rise and high tides in Honolulu, Hawaii. Water Res. 2017, 114, 122-134. [CrossRef]

37. Gallien, T.W.; Schubert, J.E.; Sanders, B.F. Predicting tidal flooding of urbanized embayments: A modeling framework and data requirements. Coast. Eng. 2011, 58, 567-577. [CrossRef]

38. Bates, P.D.; De Roo, A.P.J. A simple raster-based model for flood inundation simulation. J. Hydrol. 2000, 236, 54-77. [CrossRef]

39. Paprotny, D.; Morales-Nápoles, O.; Vousdoukas, M.I.; Jonkman, S.N.; Nikulin, G. Accuracy of pan-European coastal flood mapping. J. Flood Risk Manag. 2018, 12, e12459. [CrossRef]

40. Poulter, B.; Halpin, P.N. Raster modelling of coastal flooding from sea-level rise. Int. J. Geogr. Inf. Sci. 2007, 22, 167-182. [CrossRef]

41. Rotzoll, K.; Fletcher, C.H. Assessment of groundwater inundation as a consequence of sea-level rise. Nat. Clim. Chang. 2012, 3, 477-481. [CrossRef]

42. Habel, S.; Fletcher, C.H.; Rotzoll, K.; El-Kadi, A.I.; Oki, D.S. Comparison of a simple hydrostatic and a data-intensive 3D numerical modeling method of simulating sea-level rise induced groundwater inundation for Honolulu, Hawai'i, USA. Environ. Res. Commun. 2019, 1, 041005. [CrossRef]

43. Bloetscher, F.; Romah, T. Tools for assessing sea level rise vulnerability. J. Water Clim. Chang. 2015, 6, 181-190. [CrossRef]

44. Bloetscher, F.; Sairam, N.; Nagarajan, S.; Berry, L.; Hoermann, S. Assessing Sea Level Rise Vulnerability and Costs in a Data Limited Environment. Int. J. Eng. Technol. Manag. Res. 2017, 4, 13-31. [CrossRef]

45. Cooper, H.M.; Chen, Q.; Fletcher, C.H.; Barbee, M.M. Assessing vulnerability due to sea-level rise in Maui, Hawai'i using LiDAR remote sensing and GIS. Clim. Chang. 2012, 116, 547-563. [CrossRef]

46. Cooper, H.M.; Zhang, C.; Selch, D. Incorporating uncertainty of groundwater modeling in sea-level rise assessment: A case study in South Florida. Clim. Chang. 2015, 129, 281-294. [CrossRef]

47. Hummel, M.A.; Berry, M.S.; Stacey, M.T. Sea Level Rise Impacts on Wastewater Treatment Systems Along the U.S. Coasts. Earth's Future 2018, 6, 622-633. [CrossRef]

48. Knott, J.F.; Daniel, J.S.; Jacobs, J.M.; Kirshen, P. Adaptation Planning to Mitigate Coastal-Road Pavement Damage from Groundwater Rise Caused by Sea-Level Rise. Transp. Res. Rec. J. Transp. Res. Board 2018, 2672, 11-22. [CrossRef]

49. McLeod, G.M.; Allen, T.R.; Behr, J.G. Geospatial Risk Assessment of Marine Terminal Infrastructure to Storm Surge Inundation and Sea Level Rise. Transp. Res. Rec. J. Transp. Res. Board 2018, 2672, 19-29. [CrossRef] 
50. Novac, J. Quality Assessment of Elevation Data. In Digital Elevation Model Technologies and Applications: The DEM Users Manual, 3rd ed.; Maune, D.F., Nayegandhi, A., Eds.; American Society for Photogrammetry and Remote Sensing: Bethesda, MD, USA, 2018; pp. 455-544.

51. Temme, A.J.A.M.; Heuvelink, G.B.M.; Schoorl, J.M.; Claessens, L. Geostatistical Simulation and Error Propagation in Geomorphometry. In Developments in Soil Science; Hengl, T., Reuter, H.I., Eds.; Elsevier: Amsterdam, The Netherlands, 2009; Volume 33, pp. 121-140.

52. Wechsler, S.F.; Kroll, C.N. Quantifying DEM uncertainty and its effect on topographic parameters. Photogramm. Eng. Remote Sens. 2006, 72, 1081-1090. [CrossRef]

53. Enwright, N.; Wang, L.; Borchert, S.; Day, R.; Feher, L.; Osland, M. The Impact of Lidar Elevation Uncertainty on Mapping Intertidal Habitats on Barrier Islands. Remote Sens. 2017, 10, 5. [CrossRef]

54. Torio, D.D.; Chmura, G.L. Assessing Coastal Squeeze of Tidal Wetlands. J. Coast. Res. 2013, 290, $1049-1061$. [CrossRef]

55. Fisher, P. Improved modeling of elevation error with Geostatistics. GeoInformatica 1998, 2, 215-233. [CrossRef]

56. Hunter, G.J.; Goodchild, M.F. Dealing with error in spatial databases: A simple case study. Photogramm. Eng. Remote Sens. 1995, 61, 529-537.

57. Zerger, A.; Smith, D.I.; Hunter, G.J.; Jones, S.D. Riding the storm: A comparison of uncertainty modelling techniques for storm surge risk management. Appl. Geogr. 2002, 22, 307-330. [CrossRef]

58. Amante, C.J. Uncertain seas: Probabilistic modeling of future coastal flood zones. Int. J. Geogr. Inf. Sci. 2019, 33, 2188-2217. [CrossRef]

59. Fereshtehpour, M.; Karamouz, M. DEM Resolution Effects on Coastal Flood Vulnerability Assessment: Deterministic and Probabilistic Approach. Water Resour. Res. 2018, 54, 4965-4982. [CrossRef]

60. Fraile-Jurado, P.; Álvarez-Francoso, J.I.; Guisado-Pintado, E.; Sánchez-Carnero, N.; Ojeda-Zújar, J.; Leatherman, S.P. Mapping inundation probability due to increasing sea level rise along El Puerto de Santa María (SW Spain). Nat. Hazards 2017, 87, 581-598. [CrossRef]

61. Kovanen, J.; Oksanen, J.; Sarjakoski, T. Near real-time coastal flood inundation simulation with uncertainty analysis and GPU acceleration in a web environment. Comput. Geosci. 2018, 119, 39-48. [CrossRef]

62. Leon, J.X.; Heuvelink, G.B.M.; Phinn, S.R. Incorporating DEM uncertainty in coastal inundation mapping. PLoS ONE 2014, 9, e108727. [CrossRef]

63. Marbaix, P.; Nicholls, R.J. Accurately determining the risks of rising sea level. Eos 2007, 88, 441-442. [CrossRef]

64. Winans, R.; (National Oceanic and Atmospheric Administration, Honolulu, HI, USA); Carlson, E.; (National Geodetic Survey, Honolulu, HI, USA). Personal communication, 2018.

65. Amante, C.J. Estimating Coastal Digital Elevation Model Uncertainty. J. Coast. Res. 2018, 34, $1382-1397$. [CrossRef]

66. Enwright, N.M.; Griffith, K.T.; Osland, M.J. Incorporating Future Change into Current Conservation Planning: Evaluating Tidal Saline Wetland Migration along the U.S. Gulf of Mexico Coast under Alternative Sea-Level Rise and Urbanization Scenarios; USGS Data Series 969; U.S. Geological Survey: Reston, VA, USA, 2015. [CrossRef]

67. Mitsova, D.; Esnard, A.-M.; Li, Y. Using enhanced dasymetric mapping techniques to improve the spatial accuracy of sea level rise vulnerability assessments. J. Coast. Conserv. 2012, 16, 355-372. [CrossRef]

68. Storlazzi, C.D. The Impact of Sea-Level Rise and Climate Change on Department of Defense Installations on Atolls in the Pacific Ocean. (RC-2334, U.S. Geological Survey Administrative Report for the U.S. Department of Defense Strategic Environmental Research and Development Program); U.S. Geological Survey: Reston, VA, USA, 2017.

69. Gesch, D.B.; Danielson, J.J.; Palaseanu-Lovejoy, M. Inundation Exposure Assessment for Majuro Atoll, Republic of the Marshall Islands; USGS Data Release; U.S. Geological Survey: Reston, VA, USA, 2019. [CrossRef]

70. Cubasch, U.; Wuebbles, D.; Chen, D.; Facchini, M.C.; Frame, D.; Mahowald, N.; Winther, J.-G. Climate Change 2013: The Physical Basis; Contribution of Working Group I to the Fifth Assessment Report of the Intergovernmental Panel on Climate Change; Cambridge University Press: Cambridge, UK, 2013.

71. Flick, R.E.; Chadwick, D.B.; Briscoe, J.; Harper, K.C. “Flooding” versus “Inundation”. Eos 2012, 93, 365-366. [CrossRef]

72. PacIOOS Wave Run-Up Forecast. Available online: https://www.pacioos.hawaii.edu/shoreline-category/ runup/ (accessed on 15 August 2019). 
73. Anderson, T.R.; Fletcher, C.H.; Barbee, M.M.; Romine, B.M.; Lemmo, S.; Delevaux, J. Modeling multiple sea level rise stresses reveals up to twice the land at risk compared to strictly passive flooding methods. Sci. Rep. 2018, 8, 14484. [CrossRef]

74. Barnard, P.L.; Erikson, L.H.; Foxgrover, A.C.; Hart, J.A.F.; Limber, P.; O’Neill, A.C.; van Ormondt, M.; Vitousek, S.; Wood, N.; Hayden, M.K.; et al. Dynamic flood modeling essential to assess the coastal impacts of climate change. Sci. Rep. 2019, 9, 4309. [CrossRef]

75. Sampson, C.C.; Fewtrell, T.J.; Duncan, A.; Shaad, K.; Horritt, M.S.; Bates, P.D. Use of terrestrial laser scanning data to drive decimetric resolution urban inundation models. Adv. Water Resour. 2012, 41, 1-17. [CrossRef]

76. Mean Sea Level Trend 720-017 Majuro B \& C, Marshall Islands. Available online: https://tidesandcurrents. noaa.gov/sltrends/sltrends_global_station.shtml?stnid=720-017 (accessed on 15 August 2019).

77. DeConto, R.M.; Pollard, D. Contribution of Antarctica to past and future sea-level rise. Nature 2016, 531, 591-597. [CrossRef] [PubMed]

78. Webb, A.P.; Kench, P.S. The dynamic response of reef islands to sea-level rise: Evidence from multi-decadal analysis of island change in the Central Pacific. Glob. Planet. Chang. 2010, 72, 234-246. [CrossRef]

C 2020 by the authors. Licensee MDPI, Basel, Switzerland. This article is an open access article distributed under the terms and conditions of the Creative Commons Attribution (CC BY) license (http://creativecommons.org/licenses/by/4.0/). 